\title{
The Implementation of School Based Management to Increase Teacher's Professionalism in Vocational School
}

\author{
Gita Apriani Nur Arofah, Aniek Hindrayani, Jonet Ariyanto
}

Universitas Sebelas Maret

gitaapri@gmail.com

\section{Article History}

accepted 31/01/2021

\begin{abstract}
Vocational schools are expected to increase the professionalism of teachers in guiding their students to improve learning achievement. Studying the implementation of School-Based Management by identifying factors influenced in vocational school was one of the ways to find out the answer. With the sample of vocational schools in Karanganyar district, this study used qualitative method to collect the data and by snowball sampling to choose the informant, whose directly involved in the implementation of school based management. The results of this study identified that input, process, and output proved to increase learning performance. Input can be identified from vision, mission, goals, and school targets; process can be identified from constructing planning and program of quality improvement by Strength, Weakness, Opportunity, and Threats (SWOT) analysis; while output can be drawn from evaluating program implementation and formulating new goals. Other side, limited number of teachers who were not accompanied with good understanding about school-based management encourage lower performance.
\end{abstract}

Keywords: School-based Management, learning performance, vocational school

\section{Abstrak}

Sekolah kejuruan diharapkan dapat meningkatkan profesionalisme guru dalam membimbing siswanya untuk meningkatkan prestasi belajar. Mempelajari penerapan Manajemen Berbasis Sekolah dengan mengidentifikasi faktor-faktor yang mempengaruhi di SMK merupakan salah satu cara untuk mengetahui jawabannya. Dengan sampel sekolah kejuruan di Kabupaten Karanganyar, penelitian ini menggunakan metode kualitatif untuk mengumpulkan data dan secara snowball sampling untuk memilih informan yang terlibat langsung dalam penerapan manajemen berbasis sekolah. Hasil penelitian ini mengidentifikasi bahwa input, proses, dan output terbukti meningkatkan prestasi belajar. Input dapat diidentifikasi dari visi, misi, tujuan, dan target sekolah; Proses dapat diidentifikasi dari penyusunan perencanaan dan program peningkatan kualitas melalui analisis Strength, Weakness, Opportunity, dan Threats (SWOT); sedangkan keluaran dapat diambil dari evaluasi pelaksanaan program dan perumusan tujuan baru. Di sisi lain, keterbatasan jumlah guru yang tidak dibarengi dengan pemahaman yang baik tentang manajemen berbasis sekolah mendorong kinerja yang rendah.

Kata kunci: Manajemen berbasis sekolah, penampilan pembelajaran, SMK

Social, Humanities, and Education Studies (SHEs): Conference Series https://jurnal.uns.ac.id/shes

p-ISSN 2620-9284

e-ISSN 2620-9292

This work is licensed under a Creative Commons Attribution-ShareAlike 4.0 International License. 


\section{INTRODUCTION}

Human resource development can be increase by developing the quality of human resources effectively and efficiently with one strategic tool through education. However, Indonesia has a low education index based on data released by Human Development Reports (2017) as of 0.622 . This has an impact on the weak competitiveness of human resources. Low competitiveness will increase unemployment. The number of workforce is 131.01 million people (BPS, 2018), which has an Open Unemployment Rate of $5.34 \%$, with Vocational High Schools dominating among other education levels as of $11.24 \%$.

The government implemented a policy that is by changing the system of regional autonomy, where each school has the authority to manage school resources. In line with Bandur (2012) which states that, "any model of decentralization necessarily involves certain elements of centralization". School Based Management is established in order to optimize the resources available in the school so that the maximum output produced. The term school management is often juxtaposed with the term school administration (Mulyasa, 2014: 19). Rasyid (2013: 3) states that School Based Management is the coordination and harmonization of resources that are done automatically (independently) by the school through a number of management inputs to achieve school goals within the framework of national education by involving all interest groups related to schools directly in the process decision making (participatory). School Based Management has purpose to improve management efficiency and quality for education in school (Supriono \& Sapari ini Sri Nurabdiah, 2016: 4).

School Based Management is implemented in all schools including in the Central Java region. This research was taken at five vocational schools in the Karanganyar District. The five schools have implemented School-Based Management which is known from the differences in the rules made by each school. Based on data on national exam scores obtained from www.kemendikbud.go.id, the five schools have an average of national exam scores from 2015-2017 which declined and survivedq at sixty. This is caused by several factors, one of which is the lack of understanding of students when getting material during the learning process. This relates to one of the teacher's competencies namely pedagogical aspects, where this aspect is the teacher's ability to manage learning including student understanding, design and implementation of learning, and student development (Mulyasa, 2013: 75)

The quality of the learning process that is not optimal will produce low output so that the impact on the declining quality of human resources produced by the school. Engkoswara in Mulyasa (2014: 84) argues that the success of education management is educational productivity which can be seen in achievement or effectiveness and in efficiency. The aspects of effectiveness include equitable input, high quality and high output, knowledge and output that is in tune with the needs of the developing community, graduated income and adequate output. The indicators of the success of School Based Management according to Jones (Rahayu, 2012) include two things, (1) educational input, namely the socialization carried out by the principal to all elements of the school, identifying the real challenges of the school, formulating the school's vision, mission, goals, and targets, the education process which consists of conducting a SWOT analysis, alternative problem solving steps, compiling a quality improvement plan and program and implementing a quality improvement plan, and (2) education output, namely evaluating implementation and formulating new quality targets.

In addition to issues regarding the quality of the learning process, the role of stakeholders in the implementation of School Based Management has not yet been 
fully involved. Implementation of School Based Management can be achieved if school resources function properly. The role of the principal, teachers, parents, and the community of the school environment is also important in achieving the effectiveness of School Based Management. The role of stakeholders in five schools is still minimal, only dominated by the principal and teachers. While the parents of students and the school community have not contributed much to the school. This is due to the lack of socialization regarding School Based Management for all stakeholders. Based on preresearch, two out of five schools conducted socialization during the flag ceremony and at the beginning of the new school year. While the other three schools only socialize in writing with a picture attached to the classroom.

Departing from this simple matter, understanding of School-Based Management is minimal for stakeholders. When the understanding of School Based Management is low, the implementation of School Based Management is not optimal and indicators of success that include inputs, processes, and outputs are not achieved properly. This study reveals the implementation of School-Based Management in Vocational Schools with qualitative methods.

The structure of writing this article is an introduction, which contains a background of research and theoretical basis, followed by a description of the research method, results and discussion, and conclusions.

\section{METHODS}

This study uses descriptive qualitative methods to obtain more information about the implementation of School Based Management. This research was conducted in five schools namely, State Vocational School 1 Karanganyar, State Vocational School 2 Karanganyar, Private Vocational School of Muhammadiyah 2 Karanganyar, Private Vocational School of Wikarya Karangayar, and Private Vocational School of Bhina Karya Karanganyar. The sample technique used is snowball sampling. The informants consisted of school principals, deputy principals, teachers, students, school committees, and the school community. The validity of the data used in this study is triangulation of sources, where data obtained from interviews, documents, and photos are compared with each other to get the validity of the data. Analysis of the data used follows an interactive analysis model consisting of data reduction, data exposure, and drawing conclusions (Miles \& Huberman in Imam Gunawan, 2017: 211).

\section{RESULTS AND DISCUSSION}

The result from this research consist by three point based the successful of School Based management. The first point is input which come from the school. The input factor can be seen by the vision, mission, and goals of the school. The second is process. Process is related with learning in school, it means related too with curriculum from the school. The process of learning will be appear how teacher giving the subject to student. And related to teacher's professionalism. The last point is output. It consist of supervision and evaluation. The evaluation can be appear by the problem while school did the input and process. It can be increase the teachers professionalism by the evaluation from the school. The five school in Karanganyar district have been doing the three of sucsessful indicator School based management. And it will be explained with three point below. 


\section{Implementation of School Based Management in terms of input}

Based on the analysis that has been done, school management in terms of input has produced the vision, mission, and goals of the school which are the basis for managing the school. The vision, mission and goals of the school are formulated jointly which involves the school principal, foundation, deputy headmaster in all fields, teachers, and school committees. Five vocational schools that were studied put forward a sense of consensus in formulating the vision, mission, and goals of the school. The vision and mission of the five Vocational Schools in the Karanganyar District area almost all have one goal, namely to create skilled graduates according to their majors and able to be absorbed in the business and industrial world.

After formulating the vision, mission, and objectives of the school, the next step taken is to socialize these three things to all school members. The socialization carried out by the five vocational schools in general only posts the vision, mission, and goals of the school in every classroom and strategic places within the school. Whereas specifically there are two out of five schools that socialize the vision, mission, and goals of the school during the Monday flag ceremony.

\section{Implementation of School Based Management in terms of the process}

Based on the results of observations, interviews, and documentation, researchers analyzed that the effectiveness in terms of the process of implementing school management begins with preparing the school curriculum. The five Vocational Schools in the Karanganyar District generally use the 2013 curriculum but have different versions. Some use the early 2013 curriculum and the 2013 version of the 2017 curriculum. The effective learning process in the classroom is done well by all five schools. The five Vocational Schools studied have similarities, namely implementing active student learning where students are required to explore information through discussion and individuals. In the classroom educators use mediocre media when describing the material. The five schools have not fully maximized learning media in all subjects, it only applies to subjects that require practice. Each teacher in the five schools has a professional attitude that is described by making lesson plans in order to clarify the flow of learning in the classroom. This is consistent with Rahayu's (2012) research in terms of the process of stating that educators in schools still prioritize results compared to processes, so that the provision of material made makes students passive in class.

The five vocational schools in the Karanganyar District area prepare assessment of student learning outcomes in a fair, responsible, and continuous manner. A fair assessment is planned by each school. One proof of school transparency is illustrated by providing a concrete report of learning outcomes to parents of students in the form of report cards. This report card makes it easier for parents to monitor their child's development while at school.

In the implementation of School Based Management can't be separated from the role of a leader who is always ready to give direction. The important role of a school principal in the work environment has an impact on the performance to be produced. The five Vocational Schools in the Karanganyar Subdistrict have principals who lead and manage schools in their own way. The five school principals in the vocational school area Karanganyar District uphold the values of family, democratic, fair, and collegial. The headmasters of these five vocational schools guarantee the comfort of all school members, one of which is by providing space for anyone to have an opinion on anything related to the school, so that no one distinguishes one from the other. 
The important thing for schools to consider is how schools evaluate using SWOT. This analysis is useful for schools in evaluating school performance and understanding competitors out there. The principal has an important role in analyzing SWOT. Principals in five vocational schools in the Karanganyar District chose to work with their teachers and staff in analyzing SWOT. In addition to analyzing the SWOT, the headmaster is assisted by his staff and is also looking for the best solution to maintain school performance in the eyes of the community outside.

The principals in the five vocational schools also noticed how the quality of the performance of educators and education personnel in the school. Educators and education personnel are one of the influential stakeholders in the implementation of School Based Management. Therefore the principal always provides motivation for educators and education personnel without exception. One way to motivate it is by holding a meeting on a certain day to provide motivation to always be enthusiastic at work. In addition, the school also gives awards to anyone who excels so that it will increase the motivation of others at work.

\section{Implementation of School Based Management in terms of output}

Five vocational schools in the Karanganyar District area have supervision and evaluation of school performance, almost all of which are conducted by parties within the school and outside the school. The five schools supervise in the school together that involves all school members. Outside the school, in this case the supervisor of the Foundation and the supervisor of the Education Office. The five schools carry out supervision for school performance, school evaluation and teacher evaluation. Supervision of the learning process is carried out by the principal indirectly due to his busy schedule as a headmaster, so the supervision activities are not fully supervised.

School evaluations at these five vocational schools are carried out at different times, depending on the joint decisions the school makes. On average once a year and twice a year. The five schools in the vocational school of Karanganyar District gave the results of the school evaluation to the school committee. This was done to maintain good relations with the committee and provide information on what the school had done during the school year. In addition to evaluating school performance, the five vocational schools in the Karanganyar District region also conduct evaluations of educators and education staff. This evaluation is based on the ability and performance of educators and teaching staff in schools.

\section{Factors that influence the implementation of School Based Management}

Researchers found factors that influence the implementation of School Based Management divided into two types namely internal factors and external factors. Internal factors in implementing School Based Management in five vocational schools are almost all the same, namely from human resources. Human resources can come from the school community itself and outside the school who helped run the education process at school. The results showed that the existing human resources in the five vocational high schools enthusiastically took part in the education process carried out by the school. This can be seen from how they do their job according to their respective jobdesc without any burden. Muhyiddin's research results (2016) showed the same results namely the factor of school human resources has an influence on the effectiveness of the implementation of School Based Management.

The external factors in the implementation of School Based Management are those from stakeholders outside the school such as committees, parents of students, and the school community. External factors have the disadvantage of lack of socialization regarding school management to stakeholders. The socialization was 
conducted to provide information to stakeholders about the importance of school management and exposure to school programs. This lack of socialization will have an impact on the implementation of school management later.

The apathy shown in the school environment can come from internal and external parties. Based on research conducted apathy shown by internal parties who underestimate school management. Of course this will disrupt the continuity of the School Based Management process. In addition, another factor is the lack of participation of the committee in giving their opinions. The school committee is one of the important parties in the school management component, but in these five vocational schools the researchers found that the school committee still had a minimum share in the implementation of school management. This happened because of the effect of lack of socialization so that the committee felt there was no need to give full effort to the sustainability of the school program.

\section{CONCLUSSION}

This study aims to determine the implementation of school-based management in vocational schools both public and private schools. The results found that the implementation of School-Based Management was superior to those implemented by schools that had a public status compared to the private sector. This can be seen from the socialization of vision and mission sub-indicators where schools with public status socialize verbally and in writing, while the other three schools only do socialization with writing.

In addition, significant differences are found in the learning process subindicator where educators from three schools with private status have not maximized the existing learning media. So the learning is monotonous and makes students tend to be passive. Unlike the two other schools where educators have carried out learning by having more discussions in the classroom, so students are not passive. 


\section{REFFERENCES}

Abulencia, A. S. (2012). School-based management: A structural reform intervention. Philippine Normal University, June, 1-30.

Alhogbi, B. G. (2017). 済無No Title No Title. Journal of Chemical Information and Modeling, 53(9), 21-25. http://www.elsevier.com/locate/scp

Ayeni, A. J., \& Ibukun, W. O. (2013). A Conceptual Model for School-Based Management Operation and Quality Assurance in Nigerian Secondary Schools. Journal of Education and Learning, 2(2). https://doi.org/10.5539/jel.v2n2p36

Badan Pusat Statistik. 2018. Agustus 2018: Tingkat Penangguran Terbuka (TBT) sebesar 5,34\%. https://www.bps.go.id/pressrelease/2018/11/05/1485/agustus2018--tingkat-pengangguran-terbuka--tpt--sebesar-5-34-persen.html. [diunduh pada tanggal 28 November 2018]

Bandur, A. (2012). Decentralization and School-Based Management in Indonesia. Asia Pacific Journal of Educational Development, 1(1), 33-47. https://doi.org/10.6228/APJED.01.01.04

Data Pokok Pendidikan Dasar dan Menengah. http://dapo.dikdasmen.kemdikbud.go.id/sp/3/031309.

Depdiknas. 2000. Manajemen Peningkatan Mutu Berbasis Sekolah. Jakarta: Buku I konsep dan Pelaksanaan.

Grauwe, a De. (2005). School-based management ( SBM ): does it improve quality? Quality, 1-14.

Heyward, M., Cannon, R. A., \& Sarjono. (2011). Implementing school-based management in Indonesia. RTI Research Report Series. Occasional Paper. RTI International, September. https://doi.org/10.3768/rtipress.2011.op.0006.1109

Kementrian Pendidikan dan Kebudayaan. Rekap Ujian Nasional Tingkat Sekolah. https://puspendik.kemdikbud.go.id/hasil-un/. [diunduh pada tanggal 28 November 2018]

Malaklolunthu, S., \& Shamsudin, F. (2011). Challenges in school-based management: Case of a "cluster school" in Malaysia. Procedia - Social and Behavioral Sciences, 15, 1488-1492. https://doi.org/10.1016/j.sbspro.2011.03.316

Muhyiddin. 2016. Efektivitas Manajemen Berbasis Sekolah pada SMK Negeri di Kabupaten Nunukan (studi pada SMK Negeri 1 Nunukan). Tesis. Universitas Terbuka. Jakarta. pp. 96

Mulyasa. 2013. Standar kompetensi dan sertifiksi guru. PT. Remaja Rosdakarya. Bandung. pp. 75

Mulyasa. 2014. Manajemen Berbasis Sekolah. Bandung. PT. Remaja Rosdakarya. Bandung.

Ningsih, Rahayu. 2012. Efektivitas Manajemen Berbasis Sekolah Pada Sekolah Menengah Atas Negeri 1 Tebing Tinggi Kabupaten Kepulauan Meranti. Univesitas Riau. pp. 3

Pratiwi, Sri N. 2016. Manajemen Berbasis Sekolah dalam Meningkatkan Kualitas Sekolah. Jurnal EduTech Vol. 2 No. 1. FKIP UMSU.

Rasyid, Aditya. 2013. Pelaksanaan Manajemen Berbasis Sekolah (MBS) Di SMA Negeri 4 Kota Gorontalo. KIM Fakultas Ekonomi dan Bisnis Universitas Gorontalo. pp. 2

Pratiwi, S. N. (2016). Manajemen Berbasis Sekolah Dalam Meningkatkan Kualiats Sekolah. Jurnal EduTech, 2(1), 86-96.

Rawung, F. (2015). The Implementation of School-Based Management to Alleviate the Quality of Education in High Schools and Vocational Schools in Minahasa Regency. International Journal of Humanities and Social Science Invention, 4(7), 
SHEs: Conference Series 4 (3) (2021) 81- 88

$53-64$.

Sabii, H. (2014). Implementasi Manajemen Berbasis Sekolah (MBS) di SMPN 11 Kota Jambi. Jurnal Sainmatika, 8(1), 1-12.

Setyaningrum, N. (2014). Fakultas Keguruan Dan IImu Pendidikan Universitas Sebelas Maret Surakarta. 0271, 16.

Subarsono. 2011. Analisis Kebijakan Publik (Konsep, teori, danAplikasi). Yogyakarta: Pustaka Pelajar.

Winarno, Budi. 2012. Kebijakan Publik Teori, Proses, dan Studi Kasus. Yogyakarta: CAPS.

Yau, H. K. (2014). Principals and Teachers' perceptions of School-Based Management. International Education Research, 2(1), 44-59. https://doi.org/10.12735/ier.v2i1p44

Zengele, T. (2015). the Advent of School Based Management in the 21St Century. EBangi, 12(2). 